DOI: https://doi.org/10.15407/techned2018.05 $: \underline{100}$

\title{
A SIMPLIFIED CALCULATION OF MAGNETIC FIELD STRENGTH OVER THE MIDDLE OF THE GAP OF DOUBLE-POLE MAGNETIC IRON SEPARATOR
}

Journal

Publisher

ISSN

Issue

Pages
Tekhnichna elektrodynamika

Institute of Electrodynamics National Academy of Science of Ukraine 1607-7970 (print), 2218-1903 (online)

No 5, 2018 (September/October)

$100-103$

\section{Author}

\section{Zagirnyak}

Kremenchuk Mykhailo Ostrohradskyi National University, 20, Pershotravneva str., Kremenchuk, 39600, Ukraine, e-mail: mzagirn@kdu.edu.ua

The extraction of undesirable ferromagnetic pieces from various granular materials transported by belt conveyors is a most difficult task owing to thick layer of the material in the middle of the conveyor belt. The problem is related to derivation of the approximate formula for initial value of magnetic field strength at the points located over the middle of the gap between the inclined pole pieces of U-shaped magnetic system. The desired expression is obtained by the known formula for the plane-parallel field of two infinite plates in the same plane. The expression for calculation of the field between the inclined surfaces of the pole pieces is obtained by transformation of such formula. The experimental verification is performed by physical model and industrial specimen. As confirmed by experiments, the proposed formula can be used to calculate magnetic filed in the suspended iron separators at preliminary stages. References 11, figures 3 , tables 2 . 
Key words: calculation of magnetic field, electromagnetic iron separator, U-shaped magnetic system, plane-parallel field of infinite plates, inclined poles.

Received: 02.03.2018

Accepted: 13.06 .2018

Published: 16.08 .2018

\section{References}

1. Zagirnyak M.V., Branspiz Y.A., Shvedchikova I.A. Magnetic separators. Design problems. Kyiv: Tekhnika, 2011. 224 p. (Rus)

2. Zagirnyak M.V., Branspiz Yu.A. Pulley magnetic separators. Kyiv: Tekhnika, 2000. 303 p. (Rus)

3. Unkelbach K.H. Magnetic separators mode of operation and applicability for the separation of materials. Köln: KHD Humboldt Wedag AG, 2010. 87 p.

4. Zagirnyak M., Branspiz U., Pai R., Nasar S. Forces in pulley-type electromagnetic separators. IEEE Trans. on Magnetics. 1986. Vol. 22. Is. 1. Pp. 66-67.

5. Smolkin R.D., Saiko O.P. The calculation of magnetic fields of double-pole magnetic systems of suspended electromagnetic iron separators. Izvestiya vuzov. Electromechanics. 1989. No 3. Pp. 12-20. (Rus)

6. Smolkin M.R., Smolkin R.D. Calculation and analysis of magnetic force acting on a particle in the magnetic field of separator. Analysis of the equations used in the magnetic methods of separation. IEEE Trans. on Magnetics. 2006. Vol. 42. No 11. Pp. 3682-3693.

7. Smolkin M.R., Smolkin R.D., Smolkin E.R. Analysis of magnetic fields and circuits in separators with plane-parallel and plane-meridian symmetry. IEEE Trans. on Magnetics. 2008. Vol. 44. No 8. Pp. 1990-2001.

8. Shyshkin A.A., Butuzov V.S. The analysis of the parameters of the magnetic systems of suspended and pulley iron separators under the conditions of the operation on one conveyor belt. Vyshcha shkola. 1985. Issue 17. Pp. 51-56. (Rus)

9. Zakharova M.S., Smolkin R.D. On the calculation of the double-pole electromagnetic iron separators. Technika. 1972. No 11. Pp. 51-56. (Rus).

10. Binns K.J., Lawrenson P.J., Trowbridge C.W. The analytical and numerical solution of 
electrical and magnetic fields. Oxford: John Wiley \& Sons, Inc., 1995. $470 \mathrm{p}$

11. Abramovits M., Stigan I. Reference book on special functions. Moskva: Nauka, 1979. 830 p. (Rus)

$\underline{\text { PDF }}$ 